\title{
Temporal Insensitivity of Willingness to Pay and Implied Discount Rates
}

\author{
SOO-IL KIM \\ kim.1269@osu.edu \\ AED Economics, The Ohio State University \\ 2120 Fyffe Road, Columbus, Ohio United States 43210 \\ TIMOTHY C. HAAB ${ }^{1}$ \\ haab.1@osu.edu \\ AED Economics, The Ohio State University \\ 2120 Fyffe Road, Columbus, Ohio United States 43210
}

September 23, 2008

\begin{abstract}
A number of studies have defined and tested the temporal sensitivity of willingness to pay to payment schemes and the resulting implied discount rates for environmental projects. We demonstrate that those studies have imposed restrictive assumptions on the structure of the willingness to pay function and the underlying decision process. We investigate the temporal sensitivity of willingness to pay using a new temporal willingness to pay function applied to a proposed oyster reef restoration program. We find that 1) holding the length of the project constant, the temporal willingness to pay for the project is the same across different payment schemes, 2) temporal willingness to pay does not vary significantly across projects of varying lengths, and 3) estimated discount rates are low relative to previous studies, but vary significantly across payment schemes and project lengths.
\end{abstract}

\footnotetext{
${ }^{1}$ Corresponding author. The authors acknowledge the generous support of the Chesapeake Bay Foundation in funding the data collection for this study.
} 


\section{Introduction}

Environmental improvement and restoration projects frequently involve public expenditure over long periods of time. Despite the potential time lag, or better, time path between project initiation and the recipt of project benefits, standard cost-benefit analysis technique often take place in a static setting. Understanding the relationship between public good provision and individual elicited willingness to pay over time is thus critical for accurate benefit cost analysis.

Two interrelated anomalies associated with elicited willingness to pay for public goods related projects over time have been noted: temporal insensitivity of willingness to pay (WTP) to payment schemes and variation of discount rates over time. (Crocker and Shogren 1993, Thaler 1981, Stevens et al. 1997)². Stevens et al. (1997) define two types of temporal embedding effects: strong insensitivity and weak insensitivity to payment schedule.

Strong insensitivity to payment schedule indicates the inability of respondents to differentiate between a series of payments and a lump sum payment on the project. Let $W T P_{L}$ be the lump sum willingness to pay for an entire project, and $W T P_{t}$ be the annual willingness to pay for the $t$-th year of the same project. Strong insensitivity is defined as $W T P_{L}=W T P_{1}=W T P_{2}=\cdots=W T P_{T}$ and algebraically implies an infinite discount rate. Weak insensitivity allows for inequality of individual $W T P$ between two temporally differentiated payment schemes but implies abnormally high implied discount rates ${ }^{3}$.

Kahneman and Knetsch (1992) find evidence of strong insensitivity of median WTP for funding a toxic waste treatment facility wherein respondents showed the same lump sum median willingness to pay $\left(W T P_{L}\right)$ and annual willingness to pay $\left(W T P_{t}\right)$ over a fiveyear payment scheme. On the other hand, a series of papers (Rowe et al. 1992, Stevens et al. 1997, Ibáñez and McConnell 2001, Bond et al. 2002) reject strong insensitivity but find

\footnotetext{
${ }^{2}$ In addition to the temporal embedding effect, scope and scale embedding effects have been reported in the contingent valuation studies. Moral satisfaction (Kahneman and Knetsch 1992; Diamond and Hausman 1994), symbolic bias (Mitchell and Carson 1989), or design and analysis product (Smith 1992; Hanemann 1994) are known to be responsible for scope and scale embedding effects.

${ }^{3}$ The definition of weak insensitivity is debatable since we first have to define an abnormally "high' discount rate. For example, the discount rate in the market varies from $1 \%$ for savings accounts to over $30 \%$ for some types of credit card debt. In some developing or under developed countries, more than $100 \%$ market discount rates have been reported.
} 
weak insensitivity of WTP with discount rates ranging from two digits to several thousand percent ${ }^{4}$.

Previous studies for valuing intertemporal environmental projects have inadvertently imposed strong assumptions on the underlying decision process of a subject. By assuming that the present value of willingness to pay $(P V W T P)$ is constant across all payment schemes, they automatically assume a variance for the conditional distribution of PVWTP that is invariant to the payment schedule ${ }^{5}$. But, if PVWTP is not invariant, then we cannot compare two present values from different payment schemes, and as we will show, if $P V W T P$ is heteroskedastic across different payment schedules, the variance is unidentified ${ }^{6}$. Identification and estimation of the discount rate by varying the payment scheme relies critically on the assumption of a consistent and homoskedastic PVWTP independent of payment context.

In this paper, we relax the strong assumptions in previous studies and derive implied discount rates by redefining the temporal insensitivity of willingness to pay and testing for consistency and heteroskedasticity. To alleviate restrictive assumptions about the PVWTP, we define an alternative temporal-dimensioned valuation process for environmental projects, temporal willingness to pay (TWTP). The new concept of temporal willingness to pay is used to redefine temporal insensitivity of $W T P$ to payment schemes. We then show how to derive and test implied discount rates from temporal willingness to pay responses. To foreshadow the final results, we show that TWTP derived from a value elicitation survey on oyster reef restoration programs in the Chesapeake Bay does not vary by payment scheme or the benefit stream offered in the survey and implied discount rates vary significantly across the length of project life and time span of the offered payment schedules.

\footnotetext{
${ }^{4}$ Relatively high implicit discount rates are found in experimental research as well. Harrison and Johnson (2002) and Harrison et al. (2002) report 28.1 percent individual discount rates in average over all subjects in a field experiment in Denmark. Coller, Harrison and Rutström (2002) provide a similar experimental result. ${ }^{5}$ Haab et al. (1999) test the consistency of WTP under real and hypothetical formats. They find that correcting for heteroskedasticity yields similar estimates of WTP across different question formats. Huhtala (2000) investigates heterogeneous preferences in the contingent valuation method by distinguishing preferences according to the respondent's attitude on environmental policy. He finds that heterogeneity in preferences explains differences WTP estimates.

${ }^{6}$ More on this in section 2.
} 


\section{Present Value of Willingness to Pay vs. Temporal Willingness to Pay}

Environmental projects, by their nature, include a temporal dimension to benefits and costs. Suppose that a proposed project consists of a stream of annual benefits $B_{t}, t=1$, $2, \ldots, T_{B}$ and an associated stream of annual costs, $C_{t}, t=1,2, \ldots, T_{C}$, where $T_{B}$ represents the life of the benefits of the project and $T_{C}$ is the life of the costs. The project is fully described by the series of benefit/cost pairs $\left(B_{t}, C_{t}\right)$. The benefit is subjective due to respondent's experience with and perceived reliability of the program, uncertainty of the future, different cognizance about the benefit stream, etc. The monetary cost of the project is subjective because respondents have their own discount factor for any offered cost stream. The basic assumption is that respondents have a well-defined value of $B_{t}$ which they can compare the monetary value of costs ${ }^{7}$.

In the previous literature, the value of the benefit stream has been represented by the present value of the stream of time separable annual WTP. Suppose that respondent $i$ has a WTP in each period that is a function of the benefit received in that time period and individual-time specific covariates $\left(x_{i, t}\right) ; W T P_{i, t}=x_{i, t}^{\prime} \beta_{t}+\varepsilon_{i, t}$, where $\varepsilon_{i, t}$ is an additive error term of respondent $i$ at period $t$ which is unknown to researcher. Then, the present value of willingness to pay $(P V W T P)$ can be expressed as the discounted sum of annual WTP;

$$
\text { PVWTP }_{i}=\sum_{t} \frac{x_{i, t}^{\prime} \beta_{t}}{(1+r)^{t-1}}+\sum_{t} \frac{\varepsilon_{i, t}}{(1+r)^{t-1}} .
$$

Two causes for concern are identified in this formulation.

First, WTP in each period depends on the perceived benefit stream and individual specific covariates that may or may not vary over time. Representing the individual specific variables by the current value generates more uncertainty in the error term since they are not realized at the moment of the survey. Second, the error term is time-dependent.

Although respondents are typically assumed to have constant covariates, such a formulation requires strong assumptions about the temporal properties of the error terms. Furthermore,

\footnotetext{
${ }^{7}$ A well-defined range of values will be enough for comparison. Moreover, the value of benefit does not have to be a monetary unit. The decision, then, will be made by comparing the benefit and cost in terms of the same but any plausible unit from a respondent. For convenience and simplicity, respondents are assumed to have well defined monetary value of benefit stream.
} 
unless the life of benefit from the project $\left(T_{B}\right)$ is constant across respondents, the estimation model does not have an i.i.d. error distribution ${ }^{8}$.

The complexity of the temporal structure of $P V W T P$ motivates an alternative definition of the valuation process. Suppose respondents have a value for the whole benefit stream rather than a value in each period. Let $\pi=\left\{B_{1}, B_{2}, \ldots, B_{T_{B}}\right\}$ be the benefit stream given in the survey. The value of the benefit stream, which we call temporal willingness to pay $(T W T P)$, is defined as a function of the full benefit stream and individual specific covariates at the moment of response to the survey,

$$
\operatorname{TWTP}_{i}=f\left(\pi, x_{i}, \beta\right)+\varepsilon_{i}
$$

where $f(\cdot)$ is a systematic component observable to the researcher and $\varepsilon_{i}$ is an unobserved random error with mean zero. The error term may be conditional on the project type and payment schemes.

Instead of assuming respondents calculate the willingness to pay for the benefits in each time period of a proposed project and then performs mental gymnastics to discount that stream of values back to the present, TWTP assumes the respondent views the entire stream of benefits as a whole and constructs a value based on the entire stream as perceived at the time of response. We think that $T W T P$ provides a reasonable and realistic valuation structure for how individuals think of an environmental project proposed in a survey, without assuming time-separable $W T P$ in each period. TWTP is time-dependent in the sense that it could be different depending on the timing of the survey administration ${ }^{9}$. The error term in the TWTP function, however, is independent of time since the structure of TWTP is static at the moment of the survey.

With this alternative definition of the willingness to pay for the benefit from a proposed project, the insensitivity of WTP to temporal payment scheme is defined such that TWTP does not change due to the payment schemes:

$$
T W T P^{l}=T W T P^{k}
$$

\footnotetext{
${ }^{8} T_{B}$ can be given in the survey explicitly by the researcher. However, a respondent may perceive the terminal period of the benefit stream to be different from that stated. In such a case, $P V W T P$ has a different time-span of discounting for each respondent.

${ }^{9}$ However, Carson et al. (1997) show that CV estimates exhibited no significant sensitivity to the timing of interviews.
} 
where 1 and $\mathrm{k}$ represent different payment schedules. The prevalent assumption in the existing literature that $P V W T P$ is same across payment schemes can be tested by comparing TWTP across different payment schemes. Since TWTP is a lump-sum value that an individual may have for the environmental project at the decision moment, the TWTP model does not require the researcher to sum the discounted errors across time or impose restrictions on the temporal relation of multi-period error terms.

The value of the cost stream for a project is typically derived in terms of the present value. Since the annual cost is usually constant across time $\left(C_{t, j}=C_{j}\right)$, the general form of present value of $\operatorname{cost}(P V C)$ is

$$
P V C=\sum_{t=1}^{T_{C}} \frac{C_{j}}{\left(1+r_{C}\right)^{t-1}}=C_{j} \beta_{C}^{j}
$$

where $j$ represents the payment schedule, $T_{C}$ is the terminal period of the cost and $r_{C}$ is discount rate of the cost stream. The discount rate or discount factor of the cost stream can be different from the discount rate of benefit stream since it depends on different factors such as market discount rate, uncertainty in the financial market, etc.

$P V C$ has parameters specific to the payment scheme. For a lump sum payment of $C_{1}$ in period 1, $P V C$ is:

$$
P V C_{1}=C_{1}
$$

implying that $\beta_{C}^{1}=1$.

$P V C$ of annual payments of $C_{2}$ over $T_{C}$ years is

$$
P V C_{2}=C_{2}\left(\frac{1+r_{C}}{r_{C}}\right)\left(1-\frac{1}{\left(1+r_{C}\right)^{T_{C}}}\right),
$$

and $\beta_{C}^{2}=\left(1+r_{C}\right)\left(1-\left(1+r_{C}\right)^{-T_{C}}\right) / r_{C}$. Finally, $P V C$ of perpetual payment of $C_{3}$ is

$$
P V C_{3}=C_{3}\left(\frac{1+r_{C}}{r_{C}}\right) .
$$

with $\beta_{C}^{3}=\left(1+r_{C}\right) / r_{C}$ when the discount rate is positive. When the coefficients of (2), (3) and (4) are identified, the discount rate of cost stream is estimated by the ratio of any pair 
of coefficient estimates. Abnormally high discount rate implies the conventional weak insensitivity of $W T P$.

\section{The Oyster Reef Restoration Program in the Chesapeake Bay}

To test the sensitivity of willingness to pay and discount rates to offered payment schemes in the new framework, we apply a unique contingent valuation survey to the study of an oyster reef restoration project in the Chesapeake Bay in Maryland. Tall reefs in the Chesapeake Bay are the primary habitat for Bay oysters, the most harvested seafood species in the Chesapeake Bay. Due to intense harvesting over more than one hundred years, very few reefs remain in the Bay and oyster populations have fallen to less than one percent of their historic maximum levels. In 2002, the Chesapeake Bay Foundation commissioned a study to measure the benefits from a proposed oyster reef restoration program (Haab, Hicks and Lipton, 2004). A phone-mail contingent valuation survey was designed to assess regional resident willingness to pay for the project. Using add-on questions to the National Marine Fisheries Service Marine Recreational Fisheries Statistics Survey random digit dial telephone survey, Haab et al recruited 1,710 subjects to participate in the follow-up mail survey. The mail survey provided a brief explanation of the role and benefits of oysters in the Bay, and then asked a referendum question about willingness to pay for oyster reef programs as well as attitude and preference towards the Chesapeake Bay, general knowledge of oyster reefs and socio-demographic questions.

The follow-up mail survey consisted of a split-sample design with two temporal versions of a hypothetical oyster reef restoration project. Each respondent received one, randomly assigned, version. Both versions of the project describe a program to restore 10,000 acres of oyster habitat and create 1,000 acres of artificial reef. The projects only varied in their time to completion and the resulting variation in completion rate. Project $\mathrm{A}$ took five-years to complete and project B took ten-years. Thus, the ten-year (five-year) restoration program accumulates at a rate of 100 (200) acres of reef restoration and 1,000 $(2,000)$ acres of habitat preservation per year.

For each restoration program, one of three temporal payment schemes were randomly offered to each respondent: 1) a one-time (lump sum) payment to a special oyster-reef restoration fund on next year's state tax return 2) an annual payment to a special oyster reef restoration fund on state tax returns over the life of the project and 3) a 
permanent annual payment to the fund on the state tax return. The final survey consisted of a $2 \times 3$ design ( 2 project lengths and 3 payment schemes). Figure 1 illustrates the structure of the survey design including bid values in each design. Bid values were determined based on pre-testing of the questionnaire with local focus groups.

[Figure 1 located here]

Respondents faced a hypothetical referendum question for the randomly assigned restoration project and payment scheme. For example, the question for the five-year project with one-time payment reads as follows;

The restoration program is estimated to cost your household a total of $\mathbf{\$} \ldots$. Your household would pay this as a special one time tax added to next year's State income tax. If an election were to be held today and the total cost to your household was \$ against the 5 year restoration program (Check one)? would you vote for or

I I would vote for the program

I would vote against the program

I do not know whether I would vote for or against the program

For annual and perpetuity payment schedules, the questions were re-worded appropriately. Each design of the payment type had a set of three bid points, from which each respondent receives one. The payment values used in the one-time payment were selected from the set of $\{\$ 50, \$ 150, \$ 300\}$. A $25 \%$ discount rate was applied to calculate the annualized payment for both the annual and perpetuity payment schemes ${ }^{10}$.

\section{Estimated Models and Results}

The simplest estimated model assumes a linear function for $f(\cdot)$ and additive error term in equation (1):

$$
\operatorname{TWTP}_{i}=\beta_{B} \pi\left(B, L, r_{b}\right)+x_{i}^{\prime} \beta+\varepsilon_{i} .
$$

Assuming a normal error distribution with mean zero, the conditional probability that a respondent $i$ will vote for a program $k$ given the payment version $j$ is

$$
\begin{aligned}
P(i \text { vote for } k \mid j) & =P\left(T W T P_{i, k} \geq P V C_{i, j}\right) \\
& =\Phi\left(\tilde{\beta}_{B} \pi_{k}+x_{i, k}^{\prime} \tilde{\beta}_{k}-C_{j} \tilde{\beta}_{C}^{j}\right)
\end{aligned}
$$

\footnotetext{
${ }^{10}$ Theoretically, the discount rate used to calculate the bids in the survey design should not affect the decision mechanism of respondents. If, however, the estimation results are sensitive to bid-design, the resulting parameter estimates can be biased or inefficient. (Kim and Haab 2004).
} 
where $\tilde{\beta}$ 's are parameters normalized by the standard error, $\sigma_{k, j}$, and $\Phi($.$) is the standard$ normal cumulative distribution function. Equation (5) is the standard probability of a vote for the project in a probit referendum model and the probability of vote against is defined as the complement to the probability of vote for. ${ }^{11}$ Generally, the variance of the error term is conditional on the project version $(k)$ and payment scheme $(j)$. However, we cannot identify $\tilde{\beta}_{B}$ or $\tilde{\beta}_{C}$ from the conditional probability because the variable for the benefit stream is invariant to project length and payment scheme. We circumvent this problem by pooling data across different project versions or payment schemes. The reader should note that in this formulation, the coefficient on the fee is expected, $\tilde{\beta}_{C}$, to have a positive coefficient since the cost enters negatively. This is a more direct specification of the true underlying utility model than the standard practice of entering the cost as a positive and then estimating the negative of the marginal utility of income (see Haab and McConnell for details).

Table 1 shows estimation results from the five-year oyster reef restoration project and estimation results from the data pooled over the five and ten year restoration programs ${ }^{12}$. SEX is a dummy variable that is one for female. $H S, A G E$ and $E D U C$ are the size of household, age and education variables. $R E$ is an ordinal variable for ranking the role of oysters among food, economy, environment and fish habitat. $R E=1$ represents that respondent thinks environment is the most important role oysters play in the Chesapeake Bay. FIVE is a dummy indicator that equals one if individual $i$ receives the five-year restoration plan and zero otherwise. FEE1, FEE2A, FEE2B and FEE3 represent payment vectors for one-time, annual payment for five years, annual payment for ten years and perpetuity-type payment, respectively. Note that the willingness to pay for the ten-year

\footnotetext{
${ }^{11}$ See Haab and McConnell (2002) for details on estimating such models.

${ }^{12}$ Among 1,710 who participated in the mail survey, 519 observations were used for the analysis after dropping incomplete responses. To remain conservative, the 'I don't know' response is assumed to be 'vote against' response (Carson et al. 1998, Groothuis and Whitehead 1998). In most cases, response conforms to expectations with the proportion of 'vote for' responses decreasing with increases in the bid amount. However, the proportion of respondents voting for the project violates the monotonicity of probability distribution in two cases: from A1a to A1b and from B3b to B3c. These problematic features of data may distort estimation result and temporal insensitivity test because they arise in the potential tail of the distribution (Cooper and Loomis 1992, Kanninen, 1995). In nonparametric estimation, the pooled adjacent violators algorithm (PAVA) has been suggested by Kriström (1990) to provide a self-consistent bounded estimator such as Turnbull estimator for the inconsistent data.
} 
project is statistically indistinguishable from that of the five-year project that has faster provision of the identical final target quality.

[Table 1 located here]

Pooling data over payment schedules provides conditional probabilities that may vary across different projects:

$$
P(i \text { vote for } \mid k)=\Phi\left(\tilde{\beta}_{B} \pi_{k}+x_{i}^{\prime} \tilde{\beta}-\sum_{j=1}^{J} d_{j} C_{j} \tilde{\beta}_{C}^{j}\right) .
$$

where $d_{j}$ is a dummy indicator for payment type $j$. If the model is homoskedastic across project and payment scheme and if TWTP is different only in the mean across the project version, then the data can be pooled over all project versions and payment types, and the probability function of equation (5) becomes

$$
P(i \text { vote for })=\Phi\left(\sum_{k=1}^{K} d_{k} \tilde{\beta}_{k}+x_{i}^{\prime} \tilde{\beta}-\sum_{j=1}^{J} d_{j} C_{j} \tilde{\beta}_{C}^{j}\right)
$$

The consistency of TWTP and constant variance in equations (6) and (7) are strong assumptions that will be subsequently relaxed and tested. Table 2 and 3 report the estimation results of equation (6) pooling all possible combination of payment types for the five-year project data and estimation result of equation (7) for pooled data over projects, respectively. The scaled model will be explained in the next section.

[Table 2 - 3 located here]

One of advantages of the TWTP formulation is the flexibility in the functional form of the systematic component. For example, assuming a log normal error distribution, we can estimate nonnegative WTP using an exponential WTP function ${ }^{13}$. The functional expression for exponential TWTP is $T W T P_{i, k}=\exp \left(\beta_{B} \pi_{k}+x_{i, k}^{\prime} \beta_{k}+\varepsilon_{i, k, j}\right)$, where $\varepsilon_{i, k, j}$ is a normal error distribution with mean zero and variance $\sigma_{k, j}^{2}$. In this formulation, the parameter estimate of log bid is independent of the discount factors because by construction, the discount factor is isolated from the bid variable: $\ln \left(C_{j}\right)+\ln \left(\beta_{C}^{j}\right)$. However, since $\beta_{C}^{j}$ is invariant in the split sample, the split sample model cannot identify the discount factor of cost stream. With consistent TWTP and lump-sum payment schedule, a pooled model over

\footnotetext{
${ }^{13}$ See Haab and McConnell
} 
payment schemes can provide estimates of the discount factor of the cost stream since $\ln \beta_{C}^{j=1}=0$.

\section{A Sequential Test for Temporal Insensitivity of TWTP and Implied Discount Rates}

In the $P V W T P$ model, the procedure for testing temporal insensitivity and estimating implied discount rates assumes that $P V W T P$ 's are consistent and error terms are invariant across payment schemes. Violations of the consistency causes PVWTP and discount rates to be unidentified, and violation of homoskedasticity requires more careful calculation in deriving implicit discount rates. If consistency and homoskedasticity are not rejected then the implied discount rate can be calculated based on the test result.

The null hypothesis for testing consistency and homoskedasticity of TWTP across payment schemes is:

$$
H_{0}=\left\{\begin{array}{c}
\beta_{B}^{l}=\beta_{B}^{m} \\
\sigma_{l}=\sigma_{m}
\end{array}\right\}
$$

where $l$ and $m$ indicate different payment schemes. A sequential test proposed by Swait and Louviere (1993) for combining data from different data sources and adapted by Haab, Huang and Whitehead (1993) to a contingent valuation framework, provides a context for the sequential testing of consistency and homoskedasticity.

In the first stage, the composite hypothesis tests the consistency of TWTP

$\left(H_{0}^{A}=\left\{\beta_{B}^{l}=\beta_{B}^{m}\right\}\right)$, without restriction on variances across payment schemes. Conditional on failing to reject the first stage null hypothesis of equal parameter vectors, the second stage tests the hypothesis of invariance of the error term across payment schemes ( $H_{0}^{B}=\left\{\sigma_{l}=\sigma_{m}\right\}$ ). In both stages, LR (Likelihood ratio) provides simple test statistics.

The testing procedure can be conducted as follows. To test the first hypothesis $H_{0}^{A}$, the unconstrained model is the split sample data reported in Table 1. The constraint of the restricted model is the equality of parameters of TWTP across payment schemes without restriction on the variance. The restricted model, called the scaled model, is estimated by normalizing the variance of one sub-sample (i.e., lump-sum payment scenario) and estimating the relative variances of the other two sub-samples. The positive standard 
deviation for the pooled data is defined as $\sigma_{j}=\sigma \exp \left(\delta^{\prime} w_{j}\right)=\sigma \exp \left(\delta_{2} d_{2}+\delta_{3} d_{3}\right)$, where $\sigma$ is the standard error of lump-sum payment scenario.

If the first stage hypothesis is rejected, then stop the test procedure. Rejection of the first hypothesis indicates that respondents change their values of the environmental project depending on the payment scheme. In such a case, TWTP is inconsistent across payment schemes and a unique implicit discount rate cannot be identified. Conditional on the failure to reject the first hypothesis, the second step is to test heteroskedasticity across payment schedules. The unrestricted conditional model in the second stage is the scaled model used as the restricted model in the first stage. The restricted conditional model is the pooled data model stacking all samples across payment schemes with equal parameters in TWTP and dummies for payment scheme.

\section{Test Results}

The five-year project and five and ten-year project have been tested for consistency and homoskedasticity of TWTP by pooling data over all possible combination of the three payment schemes. Table 1 provides the split sample estimates for each project version A and $\mathrm{AB}$ (five-year and five and ten-year combined). The log likelihood of the unrestricted model is $\ln \left(L_{u}\right)=\sum_{j=1}^{J} n_{j} \cdot \ln \left(L_{j}\right)$, where $n_{j}$ is the number of observations. For instance, the unrestricted log likelihood of A1 vs. A2 is -105.52. The restricted log likelihood is the log likelihood of the scaled model for the corresponding combination of payment schedules in Table 2. For A1 vs. A2, the restricted log-likelihood value is -108.74 . The LR test statistic for the hypothesis of A1 and A2 is 6.44, which is reported in Table 4. We fail to reject the consistency hypothesis for A1 and A2 with $95 \%$ confidence.

The next step of the test is to compare the scaled model and pooled model. The restricted conditional model for five-year project is reported under the title of "pooled" in Table 2 (for AB model, Table 3). For A1 and A2, the restricted conditional log likelihood value is -109.51 , thus the LR statistic is 1.43 with degrees of freedom of one. The sequential test with $\mathrm{A} 1$ and $\mathrm{A} 2$ shows that respondents value the oyster reef restoration project consistently and the error terms have identical variances.

Table 4 reports test results for all possible combinations of project lengths and payment schemes. LR1 is the test statistics for the first stage, consistency of TWTP across 
payment schemes, and LR2 is the test statistic for homoskedasticity conditional on the first stage. Only the combination of five and ten-year project over one-time and perpetuity payment schemes $(\mathrm{AB} 1+3)$ rejected the first stage of the sequential test, $\beta_{B}^{j}=\beta_{B}^{k}$. Except $A B 1+3$ for which the second stage test is not necessary, test results of the second hypothesis show that the variance of TWTP is not statistically different across the payment type. Consequently, test results support that respondent constructs the value of oyster reef restoration programs independently from the payment schedule determined by researcher. [Table 4 located here]

The test result enables us to pool data across payment schemes and to derive the implied discount rate. Using the formula in equations (2), (3) and (4), we can derive implied discount rate from the parameter estimates associated with payments. From the results of the sequential test, the estimate of $P V C$ is the normalized parameter on the offered bid divided by the common standard deviation $\sigma$. If the standard deviation of the error term is constant across payment type, then the implied discount rate is

$$
r_{C}=\frac{\tilde{\beta}_{C}^{1}}{\tilde{\beta}_{C}^{3}-\tilde{\beta}_{C}^{1}}
$$

from equations (2) and (4) or the solution to the nonlinear function:

$$
\frac{\tilde{\beta}_{C}^{2}}{\tilde{\beta}_{C}^{1}}=\left(\frac{1+r_{C}}{r_{C}}\right)\left[1-\frac{1}{\left(1+r_{C}\right)^{T_{C}}}\right]
$$

from equations (2) and (3). If the discount rate varies on time intervals, $\tilde{\beta}_{C}^{2}$ and $\tilde{\beta}_{C}^{3}$ provide different estimates of the implied discount rate. If the test of the second stage is rejected, we can estimate the implied discount rate using parameter estimates in scaled data model as follows:

$$
\frac{\tilde{\beta}_{C}^{3}}{\tilde{\beta}_{C}^{1}}=\frac{\sigma_{1}}{\sigma_{3}}\left(\frac{1+r_{C}}{r_{C}}\right)=\frac{1}{\exp \left(\hat{\delta}_{3} d_{3}\right)}\left(\frac{1+r_{C}}{r_{C}}\right)
$$

and

$$
\frac{\tilde{\beta}_{C}^{2}}{\tilde{\beta}_{C}^{1}}=\frac{1}{\exp \left(\hat{\delta}_{2} d_{2}\right)}\left(\frac{1+r_{C}}{r_{C}}\right)\left[1-\frac{1}{\left(1+r_{C}\right)^{T_{C}}}\right] .
$$

where $\sigma_{j}=\sigma \exp \left(\delta_{2} d_{2}+\delta_{3} d_{3}\right)$. 
[Table 5 located here]

Table 5 reports various implied discount rates from all possible combinations using equation (8) and (9), and using the relation between $\tilde{\beta}_{C}^{2}$ and $\tilde{\beta}_{C}^{3}$. Except cases in which estimates are insignificant, implied discount rates ranged from $20 \%$ to more than $100 \%$. Estimated discount rates are still relatively high but much lower than previous studies. For the five year project, the short term discount rate (or near-term discount rate, $r_{1 \mathrm{~A}}$ ) is larger than the long term discount rate (or distant-term discount rate, $r_{13}$ ) implying hyperbolic discounting (e.g., see Cropper and Laibson 1999).

Finally, Table 6 reports the estimate of the expected TWTP and its 95 percent Krinsky-Robb confidence interval. TWTP of the one-time payment scheme used the estimation result of the split sample in Table 1 and the other TWTP's were estimated based on consistency and homoskedasticity of TWTP. TWTP for oyster reef restoration programs in Chesapeake Bay are \$263 277 for five-year project in the five-year project only, \$216 234 for five-year project and \$181 198 for ten-year project using the combined data. While we expected WTP for the five year project to be higher than that for the ten year project, because the five-year project provides the benefit stream faster than ten-year project does, the difference between TWTP for the two projects is not statistically significant.

[Table 6 located here]

\section{Conclusions}

Previous studies have defined and tested the temporal insensitivity of willingness to pay to payment schemes in terms of the present value of willingness to pay. Unfortunately, those studies have imposed the restrictive assumptions that the willingness to pay is timeseparable and the present value of willingness to pay is identical across different payment schemes. In this paper, we redefine the temporal insensitivity of willingness to pay in terms of the temporal willingness to pay. Different from the classical definition of the temporal embedding effect, the temporal insensitivity of willingness to pay demonstrates the consistency of valuation behavior independent of payment schemes. 
Using the sequential test proposed by Haab et al. (1999), we tested the assumptions of the new model using an application from oyster reef restoration programs in Chesapeake Bay. The test results show that holding the length of the project constant, the temporal willingness to pay for the project is statistically identical across different payment types. In holding the payment scheme constant, however, temporal willingness to pay does not vary significantly across project versions, which implies that at the time of the survey, respondents may value the project based on the final change in the environment but do not care how fast the benefit is supplied once the project is implemented. Estimated discount rates were high, but low in relation to previous studies, and varied significantly across payment schemes and project versions. However, the five-year project shows consistently high discount rates in the short term and low discount rate in long term indicating hyperbolic discounting. 


\section{References}

Bond, C.A., K. Giraud, and D. Larson, 2002, "Temporal Payment Issues in Contingent Valuation Analysis," presented in AAEA meeting in Long Beach, California.

Carson, R.T., W.M. Hanemann, R.J. Kopp, J.A. Krosnick, R.C. Mitchell, S. Presser, P.A. Ruud, and V.K. Smith with M. Conaway and K. Martin, 1997, "Temporal Reliability of Estimates from Contingent Valuation.” Land Economics, 73 (2): 151-63.

Carson, R.T., W.M. Hanemann, R.J. Kopp, J.A. Krosnick, R.C. Mitchell, S. Presser, P.A. Ruud, and V.K. Smith with M. Conaway and K. Martin, 1998, "Referendum Design and Contingent Valuation: The NOAA Panel's No-Vote Recommendation," Review of Economics and Statistics, 80, 335-338.

Coller, M., G.W. Harrison, E.E. Ruström, 2002, "Dynamic Consistency in the Laboratory," unpublished.

Cooper, J.C. and J. Loomis, 1992, "Sensitivity of Willingness-to-Pay Estimates to Bid Design in Dichotomous Choice Contingent Valuation Models," Land Economics 68(2), 211-24.

Crocker, T.D., and J.F. Shogren. 1993. "Dynamic Inconsistency in Valuing Environmental Goods." Ecological Economics, 7, 239-54.

Cropper, M., D. Laibson, 1999, “The Implication of Hyperbolic Discounting for Project Evaluation" in Discounting and Intergenerational Equity by Weyant. Washington, DC: Resources for the Future.

Diamond, P.A. and J.A. Hausman. 1994. "Contingent Valuation: Is Some Number Better Than No Number?” Journal of Economic Perspectives, 8 (4), 45-64.

Groothuis and Whitehead, “Does Don't Know Mean No? Analysis of 'Don't Know' Responses in Dichotomous Choice Contingent Valuation Question,” unpublished, 1998.

Haab, Timothy C., Robert Hicks and Douglas Lipton. 2004. "The Economic Benefits of Oyster Reef Restoration in the Chesapeake Bay." Chesapeake Bay Foundation Technical Report.

Haab, T.C., J. Huang, J.C. Whitehead., 1999, “Are Hypothetical Referenda Incentive Compatible? A Comment," Journal of Political Economy, 107 (1), 186-196.

Haab, T.C. and K.E. McConnell, 2002, Valuing Environmental and Natural Resources: The Econometrics of Nonmarket Valuation, Edward Elgar Publisher.

Hanemann, W.M., 1994, "Valuing the Environment Through Contingent Valuation." Journal of Economic Perspectives, 8 (4), 19-43. 
Harrison, G.W., and E. Johnson, 2002, "Estimating Individual Discount Rates for the United States: Inferences from a Natural Field Experiment," unpublished.

Harrison, G.W., M.I. Lau, M.B. Williams, 2002, "Estimating Individual Discount Rates in Denmark: A Field Experiment," Forthcoming, American Economic Review, 92.

Huhtala, A., 2000, "Binary Choice Valuation Studies with Heterogeneous Preferences Regarding the Program Being Valued," Environmental and Resource Economics 16, 263279.

Ibáñe, A.M., and K. McConnell, 2001, "Scheduling Payments and Discount Rates: Implication for Contingent Valuation in Developing Countries," unpublished.

Kahneman, D., and J.L. Knetsch, 1992, "Valuing Public Goods: The Purchase of Moral Satisfaction," Journal of Environmental Economics and Management, 22(1), 55-70.

Kanninen, B.J., 1995, "Bias in Discrete Response Contingent Valuation," Journal of Environmental Economics and Management, 28, 114-125.

Kim, S-I., and T.C. Haab, 2004, "Revisiting Bid Design Issues in Contingent Valuation," presented in AAEA meeting in Denver Colorado.

Krinsky, I. and A. Robb, 1986, "On Approximating the Statistical Properties of Elasticities," The Review of Economics and Statistics 86: 715-719.

Kriström, B., 1990, "A Non-Parametric Approach to the Estimation of Welfare Measure in Discrete Response Valuation Studies.” Land Economics 66, 135-139.

Mitchell, R.C., and R.T. Carson, 1989, Using Surveys to Value Public Goods: The Contingent Valuation Method. Washington, DC: Resources for the Future.

Rowe, R.D., W.D. Shaw, and W. Schulze, 1992, "NESTWCCA Oil Spill," in Natural Resource Damages: Law and Economics, eds. K. Ward and J. Duffield. New York: John Wiley and Sons.

Smith, V.K., 1992, "Comment: Arbitrary Values, Good Causes and Premature Verdicts." Journal of Environmental Economics and Management, 22(1), 71-89.

Stevens, T., N. DeCoteau, and C. Willis, 1997, "Sensitivity of Contingent Valuation to Alternative Payment Schedules." Land Economics, 73 (1), 140-148.

Swait, J. and J. Louviere, 1993, "The Role of the Scale Parameter in the Estimation and Comparison of Multinomial Logit Models." Journal of Marketing Research, 30, 305-14.

Thaler, R., 1981, "Some Empirical Evidence on Dynamic Inconsistency.” Economic Letters, 8: 201-7. 
Table 1: Estimation Results for Split and Pooled over Project Version

\begin{tabular}{|c|c|c|c|c|c|c|}
\hline & \multicolumn{3}{|c|}{ Five Year Project Only } & \multicolumn{3}{|c|}{ Five Year and Ten Year Project } \\
\hline & $\begin{array}{l}\text { One-Time } \\
\text { Tax }\end{array}$ & $\begin{array}{c}\text { Annual } \\
\text { Payment } \\
\text { over life of } \\
\text { project** }\end{array}$ & Perpetuity & $\begin{array}{l}\text { One-Time } \\
\text { Tax }\end{array}$ & $\begin{array}{c}\text { Annual } \\
\text { Payment } \\
\text { over life of } \\
\text { project }\end{array}$ & Perpetuity \\
\hline Const & $\begin{array}{l}-0.8726 \\
(1.0970)\end{array}$ & $\begin{array}{l}2.1975 \\
(1.2577)\end{array}$ & $\begin{array}{c}0.9891 \\
(1.4054)\end{array}$ & $\begin{array}{l}-1.0353 \\
(0.7997)\end{array}$ & $\begin{array}{l}1.3334 \\
(0.9163)\end{array}$ & $\begin{array}{l}1.1250 \\
(0.8959)\end{array}$ \\
\hline FIVE & - & - & - & $\begin{array}{c}0.2757 \\
(0.1936)\end{array}$ & $\begin{array}{l}-0.0821 \\
(0.4350)\end{array}$ & $\begin{array}{l}-0.0198 \\
(0.2183)\end{array}$ \\
\hline$R E$ & $\begin{array}{l}-0.5018^{*} \\
(0.2050)\end{array}$ & $\begin{array}{l}-0.1448 \\
(0.1674)\end{array}$ & $\begin{array}{l}-0.3698 \\
(0.2059)\end{array}$ & $\begin{array}{l}-0.2667 * \\
(0.1327)\end{array}$ & $\begin{array}{l}-0.1177 \\
(0.1454)\end{array}$ & $\begin{array}{l}-0.1781 \\
(0.1320)\end{array}$ \\
\hline HS & $\begin{array}{c}0.2077 \\
(0.1367)\end{array}$ & $\begin{array}{l}-0.0918 \\
(0.1477)\end{array}$ & $\begin{array}{c}0.0296 \\
(0.0864)\end{array}$ & $\begin{array}{c}0.0421 \\
(0.0812)\end{array}$ & $\begin{array}{l}-0.1169 \\
(0.0977)\end{array}$ & $\begin{array}{l}-0.0620 \\
(0.0678)\end{array}$ \\
\hline$S E X$ & $\begin{array}{l}0.1370 \\
(0.2842)\end{array}$ & $\begin{array}{c}0.5178 \\
(0.3229)\end{array}$ & $\begin{array}{l}-0.0473 \\
(0.3483)\end{array}$ & $\begin{array}{c}0.0567 \\
(0.1992)\end{array}$ & $\begin{array}{c}0.1954 \\
(0.2202)\end{array}$ & $\begin{array}{l}-0.3929 \\
(0.2289)\end{array}$ \\
\hline AGE & $\begin{array}{l}0.0429 * \\
(0.0121)\end{array}$ & $\begin{array}{c}0.0074 \\
(0.0130)\end{array}$ & $\begin{array}{l}-0.0053 \\
(0.0105)\end{array}$ & $\begin{array}{l}0.0316^{*} \\
(0.0077)\end{array}$ & $\begin{array}{c}0.0004 \\
(0.0086)\end{array}$ & $\begin{array}{l}-0.0057 \\
(0.0077)\end{array}$ \\
\hline EDUC & $\begin{array}{l}-0.0226 \\
(0.0504)\end{array}$ & $\begin{array}{l}-0.1074 \\
(0.0624)\end{array}$ & $\begin{array}{c}0.0554 \\
(0.0673)\end{array}$ & $\begin{array}{l}0.0351 \\
(0.0374)\end{array}$ & $\begin{array}{l}-0.0068 \\
(0.0393)\end{array}$ & $\begin{array}{l}0.0426 \\
(0.0419)\end{array}$ \\
\hline FEE1 & $\begin{array}{l}0.0033 * \\
(0.0015)\end{array}$ & - & - & $\begin{array}{l}0.0048 * \\
(0.0011)\end{array}$ & - & - \\
\hline FEE2A & - & $\begin{array}{c}0.0059 \\
(0.0042)\end{array}$ & - & - & $\begin{array}{c}0.0059 \\
(0.0041)\end{array}$ & - \\
\hline FEE2B & 一 & - & - & - & $\begin{array}{c}0.0096 \\
(0.0059)\end{array}$ & - \\
\hline FEE3 & - & - & $\begin{array}{l}0.0152 * \\
(0.0072)\end{array}$ & - & - & $\begin{array}{c}0.0068 \\
(0.0048)\end{array}$ \\
\hline $\mathbf{N}$ & 101 & 83 & 73 & 202 & 165 & 152 \\
\hline Mean $\ln (L)$ & -0.5635 & -0.5852 & -0.5566 & -0.5902 & -0.6007 & -0.5865 \\
\hline
\end{tabular}

* significant at $95 \%$ confidence level.

**All annualized payments discounted at $25 \%$. 
Table 2: Estimation Results for Pooled and Scaled Data of 5-year Project

\begin{tabular}{|c|c|c|c|c|c|c|c|c|}
\hline & \multicolumn{2}{|c|}{$\begin{array}{c}\text { All payments schedules } \\
\text { combined }\end{array}$} & \multicolumn{2}{|c|}{$\begin{array}{c}\text { One-time payment and } \\
\text { perpetuity }\end{array}$} & \multicolumn{2}{|c|}{$\begin{array}{c}\text { One-time payment and annual } \\
\text { payment }\end{array}$} & \multicolumn{2}{|c|}{$\begin{array}{c}\text { Annual payment and } \\
\text { perpetuity }\end{array}$} \\
\hline & Scaled & Pooled & Scaled & Pooled & Scaled & Pooled & Scaled & Pooled \\
\hline Const & $\begin{array}{c}0.2993 \\
(0.8034)\end{array}$ & $\begin{array}{c}0.4940 \\
(0.6379)\end{array}$ & $\begin{array}{l}-0.3034 \\
(0.9232)\end{array}$ & $\begin{array}{l}-0.0230 \\
(0.6874)\end{array}$ & $\begin{array}{l}-0.0082 \\
(0.6664)\end{array}$ & $\begin{array}{c}0.3011 \\
(0.7991)\end{array}$ & $\begin{array}{l}1.4791 \\
(1.0287)\end{array}$ & $\begin{array}{l}1.3088 \\
(0.8444)\end{array}$ \\
\hline$R E$ & $\begin{array}{l}-0.3956^{*} \\
(0.1390)\end{array}$ & $\begin{array}{l}-0.2759 * \\
(0.1053)\end{array}$ & $\begin{array}{l}-0.4685^{*} \\
(0.1732)\end{array}$ & $\begin{array}{l}-0.3510^{*} \\
(0.1384)\end{array}$ & $\begin{array}{l}-0.4227 * \\
(0.1564)\end{array}$ & $\begin{array}{l}-0.3031^{*} \\
(0.1267)\end{array}$ & $\begin{array}{l}-0.2886 \\
(0.1555)\end{array}$ & $\begin{array}{l}-0.2244 \\
(0.1264)\end{array}$ \\
\hline HS & $\begin{array}{c}0.0734 \\
(0.0848)\end{array}$ & $\begin{array}{c}0.0355 \\
(0.0628)\end{array}$ & $\begin{array}{c}0.1196 \\
(0.0977)\end{array}$ & $\begin{array}{l}0.0605 \\
(0.0687)\end{array}$ & $\begin{array}{c}0.1247 \\
(0.1069)\end{array}$ & $\begin{array}{l}0.0775 \\
(0.0983)\end{array}$ & $\begin{array}{l}-0.0018 \\
(0.0790)\end{array}$ & $\begin{array}{l}-0.0068 \\
(0.0728)\end{array}$ \\
\hline$S E X$ & $\begin{array}{c}0.2607 \\
(0.2124)\end{array}$ & $\begin{array}{c}0.2028 \\
(0.1684)\end{array}$ & $\begin{array}{c}0.2163 \\
(0.2481)\end{array}$ & $\begin{array}{c}0.1795 \\
(0.2059)\end{array}$ & $\begin{array}{c}0.2597 \\
(0.2419)\end{array}$ & $\begin{array}{c}0.2585 \\
(0.2038)\end{array}$ & $\begin{array}{c}0.1028 \\
(0.2642)\end{array}$ & $\begin{array}{c}0.1447 \\
(0.2206)\end{array}$ \\
\hline$A G E$ & $\begin{array}{l}0.0229 * \\
(0.0080)\end{array}$ & $\begin{array}{l}0.0140 * \\
(0.0062)\end{array}$ & $\begin{array}{l}0.0282 * \\
(0.0093)\end{array}$ & $\begin{array}{l}0.0164^{*} \\
(0.0070)\end{array}$ & $\begin{array}{l}0.0342 * \\
(0.0095)\end{array}$ & $\begin{array}{l}0.0254 * \\
(0.0086)\end{array}$ & $\begin{array}{c}0.0001 \\
(0.0087)\end{array}$ & $\begin{array}{c}0.0016 \\
(0.0076)\end{array}$ \\
\hline EDUC & $\begin{array}{l}-0.0114 \\
(0.0393)\end{array}$ & $\begin{array}{l}-0.0100 \\
(0.0317)\end{array}$ & $\begin{array}{c}0.0097 \\
(0.0449)\end{array}$ & $\begin{array}{c}0.0224 \\
(0.0358)\end{array}$ & $\begin{array}{l}-0.0421 \\
(0.0390)\end{array}$ & $\begin{array}{l}-0.0458 \\
(0.0375)\end{array}$ & $\begin{array}{c}0.0002 \\
(0.0512)\end{array}$ & $\begin{array}{l}-0.0139 \\
(0.0429)\end{array}$ \\
\hline FEE1 & $\begin{array}{l}0.0041 * \\
(0.0012)\end{array}$ & $\begin{array}{l}0.0032 * \\
(0.0010)\end{array}$ & $\begin{array}{l}0.0041 * \\
(0.0014)\end{array}$ & $\begin{array}{l}0.0034 * \\
(0.0012)\end{array}$ & $\begin{array}{l}0.0037 * \\
(0.0013)\end{array}$ & $\begin{array}{l}0.0029 * \\
(0.0012)\end{array}$ & - & - \\
\hline FEE2A & $\begin{array}{c}0.0063 \\
(0.0042)\end{array}$ & $\begin{array}{l}0.0064 * \\
(0.0029)\end{array}$ & - & - & $\begin{array}{c}0.0049 \\
(0.0045)\end{array}$ & $\begin{array}{c}0.0058 \\
(0.0032)\end{array}$ & $\begin{array}{c}0.0074 \\
(0.0045)\end{array}$ & $\begin{array}{l}0.0071 * \\
(0.0034)\end{array}$ \\
\hline FEE3 & $\begin{array}{c}0.0108 \\
(0.0065)\end{array}$ & $\begin{array}{l}0.0103 * \\
(0.0046)\end{array}$ & $\begin{array}{c}0.0092 \\
(0.0076)\end{array}$ & $\begin{array}{l}0.0112 * \\
(0.0052)\end{array}$ & - & - & $\begin{array}{c}0.0156^{*} \\
(0.0060)\end{array}$ & $\begin{array}{c}0.0117 * \\
(0.0053)\end{array}$ \\
\hline \multirow[t]{2}{*}{ Scale Factors } & 0.4645 & - & - & - & 0.4850 & - & $\odot .3957$ & - \\
\hline & 0.4266 & - & 0.5620 & - & - & - & - & - \\
\hline $\mathbf{N}$ & 257 & & 174 & & 184 & & 156 & \\
\hline Mean $\ln (L)$ & -0.5992 & -0.6015 & $-\odot .590 \odot$ & -0.5930 & -0.5913 & $-\odot .5951$ & -0.5929 & -0.5948 \\
\hline
\end{tabular}

\footnotetext{
* significant at $95 \%$ confidence level
} 
Table 3: Estimation Results for Pooled and Scaled Data of 5 and 10-year Project

\begin{tabular}{|c|c|c|c|c|c|c|c|c|}
\hline & \multicolumn{2}{|c|}{$\begin{array}{c}\text { All payments schedules } \\
\text { combined }\end{array}$} & \multicolumn{2}{|c|}{$\begin{array}{c}\text { One-time payment and } \\
\text { perpetuity }\end{array}$} & \multicolumn{2}{|c|}{$\begin{array}{c}\text { One-time payment and annual } \\
\text { payment }\end{array}$} & \multicolumn{2}{|c|}{$\begin{array}{c}\text { Annual payment and } \\
\text { perpetuity }\end{array}$} \\
\hline & Scaled & Pooled & Scaled & Pooled & Scaled & Pooled & Scaled & Pooled \\
\hline Const & $\begin{array}{l}-0.0422 \\
(0.6104)\end{array}$ & $\begin{array}{c}0.2748 \\
(0.4772)\end{array}$ & $\begin{array}{l}-0.5469 \\
(0.7104)\end{array}$ & $\begin{array}{l}-0.0615 \\
(0.5691)\end{array}$ & $\begin{array}{l}-0.3877 \\
(0.6948)\end{array}$ & $\begin{array}{l}-0.0870 \\
(0.5859)\end{array}$ & $\begin{array}{l}1.1265 \\
(0.6408)\end{array}$ & $\begin{array}{l}1.0837 \\
(0.6168)\end{array}$ \\
\hline FIVE & $\begin{array}{c}0.1686 \\
(0.1640)\end{array}$ & $\begin{array}{c}0.1038 \\
(0.1336)\end{array}$ & $\begin{array}{c}0.2127 \\
(0.1749)\end{array}$ & $\begin{array}{c}0.1361 \\
(0.1419)\end{array}$ & $\begin{array}{c}0.2264 \\
(0.1841)\end{array}$ & $\begin{array}{c}0.1904 \\
(0.1714)\end{array}$ & $\begin{array}{l}-0.0434 \\
(0.1958)\end{array}$ & $\begin{array}{l}-0.0452 \\
(0.1927)\end{array}$ \\
\hline$R E$ & $\begin{array}{l}-0.2293^{*} \\
(0.0999)\end{array}$ & $\begin{array}{l}-0.1595^{*} \\
(0.0760)\end{array}$ & $\begin{array}{l}-0.2361 * \\
(0.1160)\end{array}$ & $\begin{array}{l}-0.1632 \\
(0.0903)\end{array}$ & $\begin{array}{l}-0.2522 * \\
(0.1132)\end{array}$ & $\begin{array}{l}-0.1901^{*} \\
(0.0950)\end{array}$ & $\begin{array}{l}-0.1609 \\
(0.1000)\end{array}$ & $\begin{array}{l}-0.1537 \\
(0.0966)\end{array}$ \\
\hline HS & $\begin{array}{l}-0.0353 \\
(0.0601)\end{array}$ & $\begin{array}{l}-0.0426 \\
(0.0447)\end{array}$ & $\begin{array}{l}-0.0037 \\
(0.0684)\end{array}$ & $\begin{array}{l}-0.0300 \\
(0.0508)\end{array}$ & $\begin{array}{l}-0.0074 \\
(0.0717)\end{array}$ & $\begin{array}{l}-0.0179 \\
(0.0615)\end{array}$ & $\begin{array}{l}-0.0768 \\
(0.0559)\end{array}$ & $\begin{array}{l}-0.0739 \\
(0.0545)\end{array}$ \\
\hline$S E X$ & $\begin{array}{c}0.0324 \\
(0.1541)\end{array}$ & $\begin{array}{l}-0.0192 \\
(0.1184)\end{array}$ & $\begin{array}{c}-0.0195 \\
(0.1802)\end{array}$ & $\begin{array}{c}-0.0911 \\
(0.1446)\end{array}$ & $\begin{array}{c}0.1220 \\
(0.1700)\end{array}$ & $\begin{array}{c}0.0960 \\
(0.1431)\end{array}$ & $\begin{array}{l}-0.1159 \\
(0.1606)\end{array}$ & $\begin{array}{c}-0.1003 \\
(0.1544)\end{array}$ \\
\hline$A G E$ & $\begin{array}{c}0.0182 * \\
(0.0057)\end{array}$ & $\begin{array}{l}0.0102 * \\
(0.0043)\end{array}$ & $\begin{array}{l}0.0231 * \\
(0.0066)\end{array}$ & $\begin{array}{l}0.0134 * \\
(0.0051)\end{array}$ & $\begin{array}{l}0.0248 * \\
(0.0066)\end{array}$ & $\begin{array}{l}0.0178 * \\
(0.0056)\end{array}$ & $\begin{array}{c}-0.0014 \\
(0.0058)\end{array}$ & $\begin{array}{l}-0.0013 \\
(0.0056)\end{array}$ \\
\hline EDUC & $\begin{array}{c}0.0369 \\
(0.0287)\end{array}$ & $\begin{array}{c}0.0251 \\
(0.0222)\end{array}$ & $\begin{array}{c}0.0468 \\
(0.0338)\end{array}$ & $\begin{array}{c}0.0376 \\
(0.0272)\end{array}$ & $\begin{array}{c}0.0270 \\
(0.0319)\end{array}$ & $\begin{array}{c}0.0166 \\
(0.0265)\end{array}$ & $\begin{array}{c}0.0232 \\
(0.0295)\end{array}$ & $\begin{array}{c}0.0217 \\
(0.0284)\end{array}$ \\
\hline FEE1 & $\begin{array}{c}0.0053^{*} \\
(0.0009)\end{array}$ & $\begin{array}{l}0.0041 * \\
(0.0008)\end{array}$ & $\begin{array}{c}0.0051 * \\
(0.0010)\end{array}$ & $\begin{array}{c}0.0043 * \\
(0.0009)\end{array}$ & $\begin{array}{l}0.0051 * \\
(0.0010)\end{array}$ & $\begin{array}{l}0.0042 * \\
(0.0008)\end{array}$ & - & - \\
\hline FEE2A & $\begin{array}{l}0.0082 * \\
(0.0040)\end{array}$ & $\begin{array}{l}0.0072 * \\
(0.0027)\end{array}$ & - & - & $\begin{array}{l}0.0081 * \\
(0.0041)\end{array}$ & $\begin{array}{l}0.0081 * \\
(0.0029)\end{array}$ & $\begin{array}{c}0.0061 \\
(0.0032)\end{array}$ & $\begin{array}{c}0.0059 \\
(0.0030)\end{array}$ \\
\hline FEE2B & $\begin{array}{c}0.0090 \\
(0.0052)\end{array}$ & $\begin{array}{l}0.0084 * \\
(0.0035)\end{array}$ & - & - & $\begin{array}{c}0.0079 \\
(0.0054)\end{array}$ & $\begin{array}{l}0.0082 * \\
(0.0039)\end{array}$ & $\begin{array}{c}0.0095 * \\
(0.0043)\end{array}$ & $\begin{array}{l}0.0093 * \\
(0.0040)\end{array}$ \\
\hline FEE3 & $\begin{array}{c}0.0063 \\
(0.0049)\end{array}$ & $\begin{array}{l}0.0076 * \\
(0.0032)\end{array}$ & $\begin{array}{c}0.0035 \\
(0.0057)\end{array}$ & $\begin{array}{c}0.0077^{*} \\
(0.0036)\end{array}$ & - & - & $\begin{array}{l}0.0081^{*} \\
(0.0037)\end{array}$ & $\begin{array}{c}0.0074 * \\
(0.0037)\end{array}$ \\
\hline \multirow[t]{2}{*}{ Scale Factors } & 0.4744 & - & - & - & $\odot .4750$ & - & $\odot .0780$ & - \\
\hline & $\odot .5495$ & - & 0.6813 & - & - & - & - & - \\
\hline $\mathbf{N}$ & 519 & & 354 & & 367 & & 317 & \\
\hline Mean $\ln (L)$ & -0.6096 & -0.6115 & -0.6080 & -0.6117 & -0.6030 & -0.6064 & -0.6019 & -0.6019 \\
\hline
\end{tabular}


Table 4: Insensitivity and Homoskedasticity of TWTP to Temporal Payment Schemes

\begin{tabular}{|c|c|c|c|c|}
\hline & $\begin{array}{l}\text { All payments } \\
\text { schedules } \\
\text { combined }\end{array}$ & $\begin{array}{l}\text { One-time payment } \\
\text { and perpetuity }\end{array}$ & $\begin{array}{c}\text { One-time } \\
\text { payment and } \\
\text { annual payment }\end{array}$ & $\begin{array}{c}\text { Annual payment } \\
\text { and perpetuity }\end{array}$ \\
\hline \multicolumn{5}{|c|}{$\begin{array}{l}5 \text { year project } \\
\text { only }\end{array}$} \\
\hline LR1 & 15.75 & 10.23 & 6.61 & 6.57 \\
\hline LR2 & 1.16 & 1.02 & 1.43 & 0.60 \\
\hline \multicolumn{5}{|c|}{$\begin{array}{l}5 \text { and } 10 \text { year } \\
\text { projects } \\
\text { combined }\end{array}$} \\
\hline LR1 & 17.84 & $13.75^{*}$ & 5.95 & 5.07 \\
\hline LR2 & 1.93 & - & 2.49 & 0.05 \\
\hline
\end{tabular}

* Rejected in $90 \%$ confidence interval in Chi-squared distribution with d.o.f of seven.

Table 5: Implied Discount Rates

\begin{tabular}{|c|c|c|c|c|}
\hline & $\begin{array}{l}\text { All payments } \\
\text { schedules } \\
\text { combined }\end{array}$ & $\begin{array}{c}\text { One-time } \\
\text { payment and } \\
\text { perpetuity }\end{array}$ & $\begin{array}{c}\text { One-time } \\
\text { payment and } \\
\text { annual payment }\end{array}$ & $\begin{array}{l}\text { Annual payment } \\
\text { and perpetuity }\end{array}$ \\
\hline \multicolumn{5}{|c|}{5 year project only } \\
\hline${ }^{\dagger} \mathbf{r}_{13}$ & 0.46 & 0.45 & - & - \\
\hline${ }^{\ddagger} \mathbf{r}_{1 \mathrm{~A}}$ & 0.94 & - & $0.98^{*}$ & - \\
\hline$\S_{\mathbf{r}_{3 A}}$ & 0.22 & - & - & 0.20 \\
\hline \multicolumn{5}{|c|}{$\begin{array}{l}5 \text { and } 10 \text { year } \\
\text { projects combined }\end{array}$} \\
\hline${ }^{\dagger} \mathbf{r}_{13}$ & 1.20 & - & - & - \\
\hline${ }^{\ddagger} \mathbf{r}_{1 \mathrm{~A}}$ & 1.29 & - & 1.02 & - \\
\hline${ }^{\ddagger} \mathbf{r}_{1 \mathrm{~B}}$ & 0.96 & - & 1.05 & - \\
\hline$\S_{\mathbf{r}_{3 \mathrm{~A}}}$ & 0.87 & - & - & $0.38^{*}$ \\
\hline$\S_{\mathbf{r}_{3 B}}$ & N/A & - & - & N/A \\
\hline${ }^{\dagger} \mathbf{r}_{\mathrm{AB}}$ & 0.43 & - & 1.31 & $0.12^{*}$ \\
\hline
\end{tabular}

N/A indicates that coefficient of Perpetuity is less than that of other payment schedule.

* One of coefficients of FEE is not significantly different from zero.

$\dagger$ Calculated using coefficients of One time and Perpetuity in pooled data.

$¥$ Calculated using coefficients of One time and Annual in pooled data.

$\S$ Calculated using coefficients of Annual and Perpetuity in pooled data.

$\dagger$ Calculated using coefficients of 5 and 10 year Annual payments in pooled data. 
Table 6: Mean of TWTP and 95\% Interval by Krinsky-Robb Procedure

\begin{tabular}{|c|c|c|c|c|}
\hline & $\begin{array}{l}\text { All payments } \\
\text { schedules } \\
\text { combined }\end{array}$ & $\begin{array}{l}\text { One-time payment } \\
\text { and perpetuity }\end{array}$ & $\begin{array}{l}\text { One-time payment } \\
\text { and annual } \\
\text { payment }\end{array}$ & $\begin{array}{c}\text { Annual payment } \\
\text { and perpetuity }\end{array}$ \\
\hline \multicolumn{5}{|c|}{5 year project only } \\
\hline TWTP & 263.98 & 268.50 & 263.28 & 276.70 \\
\hline $95 \% \mathrm{KR}$ & $(170.48 \quad 629.97)$ & $\left(\begin{array}{ll}186.81 & 517.92\end{array}\right)$ & $\left(\begin{array}{ll}184.53 & 510.33\end{array}\right)$ & $\left(\begin{array}{ll}182.52 & 645.28\end{array}\right)$ \\
\hline \multicolumn{5}{|c|}{5 and 10 year projects combined } \\
\hline$T W T P^{*}$ & 233.49 & 218.68 & 216.99 & 233.82 \\
\hline $95 \% \mathrm{KR}$ & $(177.78 \quad 318.74)$ & $\left(\begin{array}{ll}167.45 & 296.22\end{array}\right)$ & $\left(\begin{array}{ll}165.13 & 294.56\end{array}\right)$ & $\left(\begin{array}{ll}175.86 & 324.17\end{array}\right)$ \\
\hline$T W T P^{* *}$ & 181.82 & 198.22 & 189.01 & 194.98 \\
\hline $95 \% \mathrm{KR}$ & $(126.74 \quad 249.03)$ & $(148.86 \quad 270.05)$ & (139.13 257.57) & $\left(\begin{array}{ll}139.71 & 271.92\end{array}\right)$ \\
\hline
\end{tabular}

* Temporal willingness to pay for five-year project

** Temporal willingness to pay for ten-year project 
Figure 1: The Structure of the Experimental Design for the Oyster Restoration Program in the Chesapeake Bay

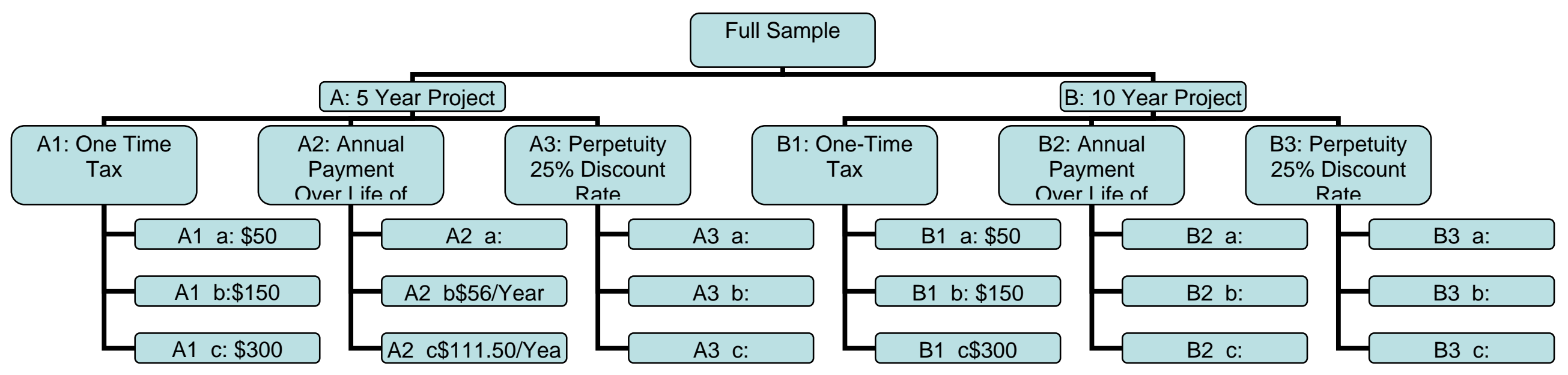

